\title{
Osallistumistulo kannustaisi nuoria opiskeluun
}

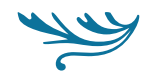

\begin{abstract}
Ilman perusasteen jälkeistä tutkintoa olevilla nuorilla työttömyys, köyhyys ja kuntoutuksen tarve ovat päällekkäisiä ja sisäkkäisiä sosiaalisia riskejä. Sosiaaliturvajärjestelmän tulisi kannustaa erityisesti vähän koulutettuja nuoria investoimaan inhimilliseen pääomaansa.
\end{abstract}

SAIN HILJATTAIN SÄHKÖPOSTIINI viestin, jossa kysyttiin mihin haluaisin käyttää viisi euroa. Vaihtoehdot olivat soijalatte, lööppilehti tai yhteisöllinen ateriahetki syrjäytyneelle nuorelle. Kyselyn lähettäjät olivat aterioiden kotitoimituksia myyvä Wolt ja kristillistä palvelutoimintaa harjoittava Helsingin Diakonissalaitoksen säätiö (HDL).

Asia kiinnosti minua paitsi siksi, että olen mainitun säätiön hallituksen jäsen, myös siksi, että laadin yhdessä tutkimusryhmänäni kanssa opetus- ja kulttuuriministeriölle (OKM) sekä sosiaali- ja terveysministeriölle (STM) selvityshenkilöraportin siitä, miten vähentää niiden nuorten määrää, jotka ovat työn, koulutuksen ja harjoittelun ulkopuolella (Hiilamo ym. 2017a). Selvityksen tavoite on - kansalaistoimintaa mitenkään väheksymättä - vaikuttaa yhteiskunnan rakenteisiin niin, että yhteisöllisiä ateriahetkiä syrjäytyneille nuorille ei tarvitsisi järjestää.

Työelämän, koulutuksen tai harjoittelun ulkopuolella olevien, niin kutsuttujen NEET-nuorten (NEET, Not in Employment, Education or Training) määrä huolestuttaa päättäjiä yhtä lailla rikkaissa ja kehittyvissä maissa (Eurofound 2012, 2016; Kraak 2013). Aihe on erityisen ajankohtainen Suomessa, jonka talous pohjautuu yhä enemmän korkeasti koulutetun väestön osaamiseen ja jossa hoivapalveluita tarvitsevan ikääntyvän väestön osuus kasvaa lähivuosina poikkeuksellisen voimakkaasti.

NEET-nuorten auttamiseksi on syntynyt viime vuosina lukuisia hankkeita. Alussa mainitun kyselyn 
NUORTEN SYRJÄYTYMISEN

EHKÄISYSS ̈̈ ON

TÄRKE $\ddot{A} \ddot{A}$ TARKASTELLA

SOSIAALITURVAJ̈̈RJESTELM $\dddot{A} \dddot{A}$.

kohde, Diakonissalaitoksen Vamos-toiminta, tukee 16-29-vuotiaita nuoria kohti koulu- ja työelämää auttamalla arjen perusasioissa, eli säännöllisen elämänrytmin löytämisessä. Merkittävä toimija on myös Me-säätiö, joka sekä toteuttaa hankkeita että tuottaa tietoa nuorten syrjäytymisestä (ks. esim. http:// www.mesaatio.fi/data/).

Nuoria koskevan sosiaaliturvajärjestelmän jäykkyydet, päällekkäisyydet, kannustinloukut ja yhteensovittamisen ongelmat kytkeytyvät yksinkertaisesti siihen, että nuorten toimeentuloa turvaa neljä keskenään hyvin erilaista järjestelmää: työmarkkinatuki, toimeentulotuki, opintotuki ja sairausperusteiset toimeentuloturvaetuudet. Asumisen tukeminen asumistuen ja toimeentulotuen kautta monimutkaistaa järjestelmää entisestään.

Erityisesti ilman perusasteen jälkeistä tutkintoa olevilla nuorilla työttömyys, köyhyys ja kuntoutuksen tarve ovat päällekkäisiä ja sisäkkäisiä sosiaalisia riskejä. Sosiaalisen investointien näkökulmasta sosiaaliturvajärjestelmän tulisi kannustaa erityisesti vähän koulutettuja nuoria jatkamaan opintojaan tai muuten investoimaan inhimilliseen pääomaansa.

Hankkeiden lisäksi nuorten syrjäytymisen ehkäisyssä on tärkeää tarkastella sosiaaliturvajärjestelmän toimintaa ja erityisesti sitä, miten se tukee vaikeassa asemassa olevien nuorten pyrkimyksiä itsenäiseen elämään.

\section{ONKO NEET-KÄSITE TARPEELLINEN?}

Se, miten puhumme ilmiöstä heijastaa sitä, mitä ajattelemme sen syistä, seurauksista ja jopa ratkaisuista. Tästä syystä monet tutkijat ovat suhtautuneet kriittisesti NEET-käsitteeseen (Follesø 2015; Furlong 2006; Serracant 2014; Yates \& Payne 2006). NEET- keskustelu nostaa ongelmaksi ne nuoret, jotka eivät ole löytäneet paikkaa aikuisten luomassa yhteiskunnassa.

'NEET' on normatiivinen ja sellaisena leimaava käsite. Se määrittelee nuorten aseman heidän itsensä ulkopuolelta. Se esittää nuorten paikan koulutuksessa, harjoittelussa ja työelämässä tavoiteltavana ja myönteisenä tilana, kun taas muut tilat määritellään pulmallisiksi. NEET-määritelmä kertoo, mitä yhteiskunta odottaa nuorilta. Se ei tunnista eikä tunnusta vaihtoehtoisia elämäntapoja. NEET-nuoret eivät kuitenkaan itse välttämättä koe olevansa ongelmallisessa tilanteessa.

Toisaalta NEET-käsite pohjautuu laajasti kannatettuun ajatukseen siitä, että nuorten on löydettävä polku, joka turvaa heille itsenäisen toimeentulon. Kaikille tämä ei ole kuitenkaan mahdollista. Ongelman ydin on, miten paljon yksilön on ponnisteltava ansaitakseen toimeentulonsa ja milloin alkaa yhteiskunnan vastuu. Millainen sosiaaliturva kuuluu esimerkiksi nuorelle, joka ei opiskele eikä etsi töitä sen vuoksi, ettei tiedä mihin haluaisi isona ryhtyä? Voidaanko tämänkaltainen "näköalan hämäryys" tulkita kykenemättömyydeksi hankkia itselle toimeentuloa? Miten koulutusjärjestelmä ja muut palvelut voisivat tukea nuoria löytämään polkuja valtavirtaan (Hiilamo 2010)?

NEET-käsite syntyi Isossa-Britanniassa 1980-luvulla. Tuolloin toteutetut sosiaaliturvan leikkaukset poistivat koulun keskeyttäneiltä nuorilta työttömyyskorvauksen ennen heidän täysi-ikäistymistään. Näin syntyi tarve uudelle tunnusluvulle, joka kuvaisi myös ilman työttömyysturvaa jääneitä nuoria. Vuoden 2008 talouslaman jälkeen NEET-käsitettä alettiin käyttää tilastollisena mittarina korkean nuorisotyöttömyyden riivaamissa maissa. Se soveltuukin nuorisotyöttömyyttä (Hämäläinen \& Hämäläinen 2012) paremmin kuvaamaan niiden nuorten määrää ja osuutta, jotka eivät ole työssä eivätkä työmarkkinoille valmistavassa toiminnassa.

\section{NEET-KÄSITE POHJOISMAISSA}

Pohjoismaisessa keskustelussa NEET-kysymys on sidoksissa ideaan universaalista hyvinvointivaltiosta, 


\section{POHJOISMAISEN}

\section{HYVINVOINTIVALTION IDEA \\ TIIVISTYY TYÖLINJAAN.}

jossa kaikki kynnelle kykenevät osallistuvat työelämään, maksavat veroja ja siten pitävät yllä edellytyksiä korkeatasoisiin tulonsiirtoihin ja palveluihin. Pohjoismaisen hyvinvointivaltion idea tiivistyy työlinjaan: kaikilla tulisi olla mahdollisuus elättää itsensä omalla työllään. Myös vammaisilla ja osatyökykyisillä tulisi olla mahdollisuus opiskella ja hankkia ainakin osa toimeentulostaan omalla työllään. On tärkeää huomata, että alhaisella koulutuksella ja työttömyydellä on "haavoittava vaikutus" (Nilsen \& Reiso 2014; Schmillen \& Umkehrer 2017), ja se heikentää nuorten työmarkkinamahdollisuuksia ja luottamusta yhteiskuntaan tulevaisuudessa. Nuorilla työttömyyden haavoittava vaikutus on poikkeuksellisen vakava, koska se kestää mahdollisesti koko lopputyöuran.

Samalla NEET-nuorten määritteleminen syrjäytyneiksi voi johtaa nuorten leimaamiseen ja siihen, että heidän vastuunsa omasta elämästään korostuu yhteiskunnan vastuun kustannuksella, mikä tekee NEET-statuksen yhä raskaammaksi kantaa. Samalla se vaikeuttaa toimia nuorten aseman parantamiseksi ja legitimoimiseksi.

Suomessa NEET-keskustelu kytkeytyy ennen muuta hallituksen tavoitteeseen työllisyysasteen nostamisesta ja valtion velkaantumisen pysäyttämisestä. Taustalla vaikuttaa lisäksi julkisen talouden näkökulmasta epäedullinen ikärakenne. Niin kutsutun huoltosuhteen korjaaminen edellyttäisi, että nuoret suorittaisivat mahdollisimman nopeasti tutkintonsa ja sijoittuisivat mahdollisimman hyvin palkattuihin ammatteihin.

Suomaiseen NEET-keskusteluun liittyy lisäksi ristiriitainen kysymys oikeudesta sosiaaliturvaan. Se on yhtäälä perusoikeus, toisaalta perustuslaki ei salli vapaamatkustamista. Perustuslain 19. pykälä käsittelee oikeutta sosiaaliturvaan. Sen ensimmäisen momentin mukaan "jokaisella, joka ei kykene hankkimaan ihmisarvoisen elämän edellyttämää turvaa, on oikeus välttämättömään toimeentuloon ja huolenpitoon".

Viime kädessä tiukasti tarveharkintainen toimeentulotuki antaa suojan ihmisten perustarpeita koskeville puutteille. Huolenpito viittaa tarpeen mukaisiin palveluihin, joista ei ole kuitenkaan säädetty - joitakin poikkeuksia lukuun ottamatta - subjektiivisia oikeuksia. On kuitenkin tärkeä huomata, että turva kuuluu vain niille, jotka eivät kykene hankkimaan itselleen ihmisarvoisen elämän edellyttämää turvaa.

\section{KEITÄ NEET-NUORET OVAT?}

Euroopan unionin elin- ja työolojen kehittämisvirasto Eurofound (2016) tarkastelee seitsemää erilaista NEET-nuorten ryhmää unionin työvoimakyselyn avulla. Jaottelu pohjaa kahteen kysymykseen: 1) "syyt siihen, ettei etsi työtä" ja 2) "syyt, miksi ei voi aloittaa työtä kahden viikon kuluessa".

Odottajien ryhmään luetaan ne nuoret, jotka ovat pian aloittamassa opiskelun, työn tai harjoittelun. Tilapäisesti työttömiin kuuluvat ne, jotka ovat olleet alle vuoden työttömänä. Pitkäaikaistyöttömät ovat olleet yli vuoden työttöminä. Kaikissa ryhmissä nuoret ovat valmiita aloittamaan työn kahden viikon kuluessa.

Neljänteen ryhmään kuuluvat ne nuoret, jotka eivät ole opiskelemassa, työssä tai harjoittelussa itse ilmoittamansa sairauden tai vamman vuoksi. Viidennessä ryhmässä osallistumattomuuden syynä ovat perhevelvollisuudet. Eurofound kutsuu kuudetta ryhmää 'lannistuneiksi työnhakijoiksi' : he eivät enää etsi työtä, koska eivät usko saavansa sitä. Seitsemäs ryhmä koostuu muista passiivisista nuorista.

NEET-ryhmään kuuluu siten sekä niitä, jotka ovat kaukana työmarkkinoista että niitä, jotka ovat itse valinneet sivuun jättäytymisen. Ryhmällä on kuitenkin yhteisiäkin piirteitä. NEET-nuoret eivät ole parantamassa työmarkkinavalmiuksiaan eli investoimassa inhimilliseen pääomaan koulutuksen, harjoittelun tai työn avulla. Statuksen kestosta riippumatta heillä on myös suurempi riski jäädä tulevaisuudessa valtavirran ulkopuolella, saada vain matala koulutus ja alhaiset tulot. 
SELVIMMin NEET-STATUKSESSA

OLEVIEN MÄÄRÄÄN VAIKUTTAVAT

TALOUSTILANNE

JA TALOUSPOLITIIKKA.

Vuoden mittainen NEET-status ei tarkoita sitä, että nuori olisi välttämättä syrjäytymässä työelämästä. Suomen vuoden 1987 ikäkohorttia koskevassa tutkimuksessa havaittiin, että peräti 46 prosenttia kaikista nuorista oli ollut ikävuosien 16 ja 25 välillä vähintään yhden vuoden NEET-statuksella (Larja ym. 2016). Monet nuoret haluavat pitää esimerkiksi välivuoden ennen kuin aloittavat opiskelun tai työelämän. NEETstatuksen taustalla voi olla pääsykokeisiin lukeminen, armeijan tai opiskelun aloittaminen ja vapaaehtoistyö tai aktiivinen harrastustoiminta. Sen sijaan pitkittynyt NEET-status on yhteydessä muun muassa nuorten toimeentulovaikeuksien ja mielenterveysongelmien lisääntymiseen ja syrjäytymiseen demokraattisesta osallistumisesta ja kansalaisyhteiskunnan toiminnasta (Larja ym. 2016; Eurofound 2012, 2016).

NEET-käsitettä voidaan kuitenkin arvostella paitsi liian laajaksi myös liian suppeaksi. Se ei tavoita kaikkien kilpailuyhteiskunnassa elävien nuorten haavoittuvuutta. Ryhmän ulkopuolellakin olevat joutuvat kamppailemaan muun muassa palkattomissa harjoitteluissa sekä osa-aika-, silppu- ja pätkätöissä. Samalla NEETstatuksen taustalla voi olla monenlaisia yksilöllisiä ja yhteiskunnallisia ongelmia, ylisukupolvista ja elämänkulun aikana kumuloitunutta huono-osaisuutta, alueellista epätasa-arvoa koskevia tekijöitä ja etnisyyteen tai sukupuoleen kytkeytyviä syrjinnän kokemuksia. Se perustuu lisäksi teollisuusyhteiskunnan aikaiselle käsitykselle lineaarisista siirtymistä koulutuksesta työelämään, vaikka nuorten elämänpolut ovat nykyisin paljon monimutkaisempia (Eurofound 2016).

\section{NEET-NUORTEN MÄÄRÄ}

Tieto NEET-nuorten määrästä Suomessa perustuu Tilastokeskuksen työvoimatutkimuksen käyttämään määritelmään "ei työssä eikä koulutuksessa eikä asevelvollisuutta suorittamassa olevien nuorten osuus". Määrittely kattaa koko ikäluokasta ne 15-24-vuotiaat nuoret, jotka eivät ole työssä, tutkintoon johtavassa koulutuksessa, kurssikoulutuksessa eivätkä varusmies- tai siviilipalveluksessa. Tilastokeskuksen työvoimatutkimuksen luku eroaa hieman Euroopan tilastoviraston Eurostatin NEET-asteesta. Eurostatin aineistossa varusmies- tai sivilipalveluksessa olevat nuoret eivät kuulu perusjoukkoon. Molempien mittareiden mukaan NEET-nuorten ryhmä on kasvanut Suomessa vuoden 2010 jälkeen muissa paitsi 15-19-vuotiaiden ryhmässä. Erityisen selvästi on kasvanut 20-24-vuotiaiden miesten NEET-aste (Alatalo ym. 2017).

Sukupuolten välistä eroa selittää se, että nuorten miesten koulutustaso on matalampi kuin naisten. NEET-asteen muutoksiin vaikuttaa sekin, että nuorisotyöttömyys on vahvasti yhteydessä talouden suhdanteisiin. Erityisesti tämä pätee nuoriin miehiin, jotka työskentelevät usein suhdanneherkillä aloilla. Lisäksi nuorilla on muita useammin määräaikaisia työsopimuksia, osa-aikatyötä ja muutoin heikko asema työmarkkinoilla. Matalasuhdanteessa nuoret jäävät ensimmäisenä jalkoihin. NEET-statuksessa olevien määrään vaikuttavatkin selvimmin taloustilanne ja talouspolitiikka (Halvorsen ym. 2012). Eurofoundin (2016) raportissa Suomen NEET-nuorten ryhmä poikkeaa Luxemburgin, Kroatian ja Kyproksen kanssa muista 28 unionin jäsenmaasta siinä, että ryhmään kuuluu selvästi enemmän poikia kuin tyttöjä. Suomessa NEET-nuoret saivat vuonna 2014 työttömyysetuuksia useammin kuin yhdessäkään muussa EUmaassa. Toisin sanoen NEET-nuorten taloudellinen asema on etuuksien saamisen näkökulmasta Suomessa parempi kuin muissa unionimaissa. Muihin EU-maihin verrattuna Suomen NEET-nuorissa on vähän maahanmuuttajia. Heidän osuutensa on selvästi suurempi esimerkiksi Hollannissa, Ruotsissa ja Tanskassa.

Lannistuneiden osuus on Suomessa suurin kuten myös NEET-aste mittausvuonna 2013. Toisaalla Eurofoundin $(2016,38)$ NEET-raportti paljastaa, että Suomessa työttömillä NEET-nuorilla on poikkeuksellisen usein työkokemusta verrattuna muiden maiden työttömiin NEET-nuoriin. Tämä kertonee siitä, että 
GLOBALISAATIOSSA ILMAN

PERUSASTEEN JÄLKEIST $\ddot{A}$

TUTKINTOA OLEVIEN

MAHDOLLISUUDET SAADA

TYÖT ̈̈ OVAT HEIKOT.

Suomen suhteellisen korkea NEET-aste on ennen muuta puuttuvan työn kysynnän aiheuttama ongelma.

Eurofoundin $(2016,35)$ mukaan pitkäaikaistyöttömien nuorten osuus on erityisen pieni maissa, joissa on kehittynyt nuorisotakuu, kuten Tanskassa, Suomessa ja Ruotsissa. EU päätti vuonna 2013 nuorisotakuusta, joka takaa kaikille alle 25-vuotiaille nuorille korkealaatuisen tarjouksen työpaikasta, opiskelusta, oppisopimuksesta tai harjoittelusta neljän kuukauden kuluessa työttömyyden alkamisesta tai tutkintoon johtavan koulutuksen päättämisestä. Suomen nuorisotakuussa ei mainita "korkealaatuista" tarjousta, mutta tarjous luvataan tehdä kolmen kuukauden kuluessa. Suomen nuorisotakuussa ovat mukana lisäksi alle 29-vuotiaat nuoret, jotka ovat edellisen vuoden aikana suorittaneet tutkintonsa.

NEET-statuksen yksilöllisiä riskitekijöitä nuorille ovat alhaisen koulutuksen lisäksi koulutuksen keskeyttäminen, kokemus lastensuojelun sijaishuollosta, maahanmuuttajatausta, teiniäitiys, fyysisen ja psyykkisen toimintakyvyn puutteet ja päihdeongelmat. NEET-riskit ja suojaavat tekijät ovat vahvasti sidoksissa nuorten aikaisempaan elämään. Riskien taustalla on vanhempiin liittyviä tekijöitä, kuten vanhempien alhainen koulutus, köyhyys ja perheväkivalta. NEET-nuorten koulumenestys on ollut usein kehno, ja he ovat voineet joutua koulukiusaamisen uhreiksi. (Hyggen 2015).

Yhtä tai muutamaa selvää riskitekijää tai suojaavaa tekijää on mahdotonta osoittaa, koska ryhmä on heterogeeninen, ja tutkimuksissa identifioidut riskitekijät ja suojaavat tekijät ovat aina yhteydessä käytettävissä olevan aineiston muuttujiin. Terveyden ja hyvinvoinnin laitoksen (THL) vuonna 1987 syntyneiden seuranta-aineisto kuvaa kattavasti suomalaisnuorten, myös NEET-nuorten, tilannetta. Aineistosta hahmottuu neljä NEET-polkua: 1) työttömyys ja toimeentulotuen saaminen, 2) työttömyyden ja silpputöiden vuorottelu, 3 ) koulutuksen tai silpputöiden ja puuttuvan tiedon vuorottelu sekä 4) polku, josta ei ole saatu juuri lainkaan tai ollenkaan rekisteritietoja. Ongelmallisena näyttäytyy myös nuorina perheellistyvien naisten ryhmä.

Polut olivat melko pysyviä kahdeksan vuoden seurannassa (Ristikari ym. 2016). Tutkimusten mukaan pitkittyneiden NEET-polkujen taustalla ovat nuoria koskevista tekijöistä erityisesti alhainen peruskoulun keskiarvo, toisen asteen tutkinnon puute ja ennen 16. ikävuotta saatu psykiatrinen diagnoosi, joka ohjaa erityisesti työttömyys- ja toimeentulotukipolulle. Vanhempiin liittyviä tekijöitä ovat pitkäaikainen työttömyys, alhainen koulutustaso ja toimeentulotuen saaminen.

\section{SOSIAALIVAKUUTUS VERSUS}

\section{SOSIAALISET INVESTOINNIT}

Suomalainen sosiaalipolitiikka on sosiaalisten riskien vastaista keskitettyä resurssien uudelleenjakoa (Anttonen \& Sipilä 2000). Sosiaalivakuutusajattelu luotiin aikana, jolloin valtiot kykenivät sääntelemään taloutta ja samalla työvoiman kysyntää. Vapaiden pääomaliikkeiden ja Euroopan rahaliiton budjettitasapainovaatimusten myötä politiikan keinot vaikuttaa työmarkkinoihin ovat supistuneet.

Työmarkkinoille tuleva, erityisesti koulutuksen hankkinut nuori haluaa ymmärrettävästi saada itselleen sopivan ja mieluisen työn, mutta työtä ei ole, jos kukaan ei sitä tarjoa. Mikäli globaalin talouden pelisääntöjä ei muuteta, työpaikkojen suojelu osoittautuu lopulta mahdottomaksi.

Sosiaalisen investoimisen ajatuksena on, että vaikka työpaikkojen suojelu on mahdotonta, työntekijöiden suojelu voi toimia, jos sosiaaliturvan vastikkeellisuus ymmärretään uudelleen. Ei riitä, että ihmiset tarjoutuvat työmarkkinoiden käytettäviksi, vaan heidän on sitouduttava kehittämään osaamistaan.

Koulutukseen kannustamisen tärkeyttä korostaa se, että globalisaation myötä ilman perusasteen 


\section{Alhainen koulutus}

NUORENA ON UUSI

SOSIAALINEN RISKI.

jälkeistä tutkintoa mahdollisuudet työmarkkinoilla ovat heikot. Suomessa vuoden 1987 jälkeen erityisen voimakkaasti on laskenut ilman perusasteen jälkeistä tutkintoa saaneiden työllisyysaste. Eurostatin (2017) mukaan 15-64-vuotiaiden työllisyysaste vain perusasteen tutkinnon suorittaneilla (ISCED 0-2) oli Suomessa 37,9 prosenttia, kun se ylemmän asteen tutkinnon suorittaneilla (ISCED 5-8) oli 82,9 prosenttia. Koulutustason mukaisten työllisyysasteiden ero on kasvanut globalisaatiossa.

Toisen asteen koulutuksen keskeyttäneiden ansiot jäävät pienemmiksi ja syrjäytymisriski suuremmaksi kuin vastaavan koulutuksen loppuun suorittaneiden. Lisäksi ilman toisen asteen tutkintoa olevien työssä käynnin määrä on vähäisempää kuin esimerkiksi keskiasteen koulutuksen suorittaneiden. (Myrskylä 2012). Pohjoismaisten tutkimusten mukaan toisen asteen tutkinnon suorittaminen suojaa tehokkaasti myös lastensuojelun sijaishuollossa olleita nuoria muutoin ryhmään kohdistuvilta suurilta riskeiltä (Kääriälä \& Hiilamo 2017).

\section{NUORTEN OSALLISTUMISTULO}

Suomen nykyisessä sosiaaliturvajärjestelmässä on merkittäviä ongelmia nuorten kannustamisessa opiskeluun ja työhön. Alhainen koulutus nuorena on niin kutsuttu uusi sosiaalinen riski, johon tulisi tarttua uusilla toimilla ja uudella etuudella.

Ainakin lyhyellä tähtäimellä nuoren on kannattavampaa ottaa vastaan työmarkkina- ja toimeentulotukea kuin opiskella tai käydä työssä pienimuotoisesti. Yksi yhteinen nuorten sosiaaliturvaetuus tekisi sosiaaliturvajärjestelmästä joustavamman ja kannustavamman.

Nuorten osallistumistulo korvaisi sen kohderyhmään kuuluvilla nuorilla toimeentulotuen ja työmarkkinatuen. Toisin sanoen perustoimeentu- lotukea ja työmarkkinatukea ei myönnettäisi ilman ammatillista tutkintoa oleville alle 25-vuotiaille eikä vain lukiokoulutuksen varassa oleville. Kunnille jäisi mahdollisuus myöntää nuorille täydentävää ja ehkäisevää toimeentulotukea.

Toimeentulon turvaavan tulon tai etuuden hankkiminen on kaikille kansalaisille, erityisesti ilman vanhempien tukea oleville nuorille, ehdoton välttämättömyys. Nuorten taloudellisen tuen tarve antaa palvelujärjestelmälle mahdollisuuden kohdata nuoret. Samalla järjestelmä saa tilaisuuden tarjota heille inhimilliseen pääoman investoimiseen liittyviä palveluita, toisin sanoen kannustaa heitä koulutuksen ja työn avulla kohti itsenäistä elämää.

Nuorten osallistumistulolla eli etuudella sekä siihen liittyvällä velvoittavalla toiminnalla ja palveluilla voitaisiin ohjata ja kannustaa nuoria nykyistä paremmin opiskeluun, työhön, työpajatoimintaan, kuntouttavaan työtoimintaan tai muuhun aktiiviseen toimintaan. Yhdistetyn etuuden malli sisältyy tuoreeseen, valtioneuvostolle laadittuun selvitykseen osallistuvan sosiaaliturvan malleista Suomessa.(Hiilamo ym. 2017b). Selvityksessä ehdotetaan Suomeen Hollannin esimerkin mukaista osallistumistuloa.

\section{OSALLISTUMISTULON KOHDERYHMÄ}

Aikaisemmat tutkimukset ovat osoittaneet, että kaikille suunnatut toimet ovat tehokkaampia kuin kohdennetut toimet (Hyggen 2015). Ilman toisen asteen tutkintoa olevilla nuorilla on kuitenkin kivinen tie päästä itsenäiseen elämään. Lisäksi pitkään jatkunut NEET-status sisältää erityisiä riskejä.

Nuorten osallistumistulon ja -palveluiden ensisijaiseen kohderyhmään kuuluvat 17 vuotta täyttäneet, ilman ammatillista tutkintoa olevat alle 25-vuotiaat nuoret, jotka hakevat työttömyyden, sairauden, työkyvyttömyyden tai toimeentulon vähäisyyden perusteella toimeentulotukea Kansaneläkelaitoksesta (Kela). Nuorten osallistumistulo ja siihen liittyvät palvelut - velvoittava toiminta ja tukipalvelut - on tarkoitettu muista kuin tilapäisistä toimeentulovaikeuksista kärsiville. Toimintaan ovat velvoitettuja ne nuoret, joiden työttömyys olisi kestänyt esimerkiksi vähintään neljä kuukautta. 


\section{TyÖPAJATOIMINNASSA \\ OSAAMISEN TUNNISTAMISTA \\ ON TEHTY VUOSIA.}

Kohderyhmään eivät kuulu ansioturvan saajat eivätkä äitiys-, isyys-, vanhempainpäivärahan, kotihoidon tuen tai vaikeavammaiset vammaisetuuksien hakijat. Siihen eivät myöskään kuulu tutkintoon johtavassa koulutuksessa ja siten opintotuen piirissä olevat opiskelijat. Osallistumistulo voisi olla vapaaehtoinen vaihtoehto jo tutkinnon suorittaneille alle 29-vuotiaille nuorille. Nuorten osallistumistulo olisi Kelan maksama ja valtion rahoittama yksilökohtainen veroton etuus, jota maksettaisiin eri tasoilla: perustasolla tuen taso määräytyisi perustoimeentulotuen mukaan (täysi tai alennettu perusosa), aktiivitasolla nykyisen työmarkkinatuen tason tai tulevaisuuden yleisturvan tason mukaan ja mahdollisesti korotetulla tasolla takuueläkkeen tason mukaan. Malliin kuuluisi tulonsiirron lisäksi velvoittavaa toimintaa sekä opintoihin ja työelämään siirtymistä tukevia palveluita.

\section{OPINTOIHIN KANNUSTAMINEN}

Opintorahan ja muiden etuuksien suhde on merkittävä tekijä nuorten pohtiessa opiskelumahdollisuuksiaan ja -motivaatiotaan. Nuorten osallistumistulo on selvästi suurempi etuus kuin opintotuen opintoraha. Ero korostui syksyn 2017 opintorahan leikkauksen jälkeen. Opintotukeen kuuluu valtion takaama lainaosuus, eikä opiskelua voi suoraan verrata sosiaalisena riskinä työttömyyteen tai köyhyyteen. Lisäksi opiskelu on ilmaista, ja osan opintolainasta voi vähentää verotuksessa.

Ongelmaksi voi muodostua niin kutsuttu lukkiutumisefekti: nuoret jäävät osallistumistulolle, vaikka heidän olisi muun muassa tulevien työmahdollisuuksiensa takia kannattavampaa suorittaa tutkintoon johtavia opintoja. Toimet nuorten maksuhäiriömerkintöjen vähentämiseksi voivat madaltaa kynnystä ottaa opintolainaa. Yleinen suhtautuminen opintolainoihin saattaa muuttua opintotuen lainapainotteisuuden lisääntyessä.
Vaikeimmassa tilanteessa olevat nuoret tarvitsevat kuitenkin ylimääräistä taloudellista tukea siirtymisessä osallistumistulolta opintotuelle. Poikkeustapauksissa nuoret voisivat ainakin ylimenokauden ajan saada aktiivitason osallistumistuloa tutkintoon johtavaan koulutukseen. Käytännössä nuoret saisivat pitää määräajan osan osallistumistulosta, esimerkiksi 300 euroa kuukaudessa. Osallistumistuloa maksettaisiin opintorahan lisäksi. Esimerkiksi lastensuojelun jälkihuollossa olevat nuoret voisivat saada sen tutkintoon johtaviin opintoihin.

Tutkinnon osia olisi mahdollista suorittaa osana kuntouttavaa työtoimintaa, työkokeiluja, muuta vastaavaa palvelua tai muutoin aktiivitason osallistumistulon mukaisessa toiminnassa. Näin palveluissa olevien nuorten osaaminen tulisi tunnistetuksi ja tunnustetuksi virallisiksi tutkinnoiksi tai niiden osiksi nykyistä laajamittaisemmin. Nekin nuoret, jotka eivät kykene osallistumaan formaaliin koulutukseen, saisivat luettua hyväksi aktiivitoimissa kertyvää osaamista. Työpajatoiminnassa osaamisen tunnistamista on tehty vuosia, ja työpajat ovat kehittäneet tähän työkaluja, joita voitaisiin ottaa laajempaankin käyttöön.

Sosiaaliturvan kokonaisuudistus herätti runsaasti keskustelua keväällä 2018. Eri tahot kannattivat mallia, jossa Suomi siirtyisi yhtenäiseen perusturvaan Ison-Britannian mallin mukaisesti (ks. Maanselkä 2018). Nuorten osallistumistulo voisi tulla osaksi mallia, jos samalla otetaan huomioon syrjäytymisvaarassa olevien nuorten erityiset palvelutarpeet.

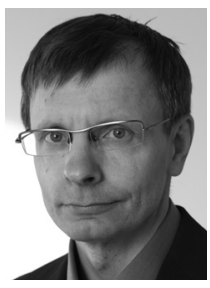

HEIKKI HIILAMO

VTT, FT, sosiaalipolitiikan professori Helsingin yliopisto

Kirjoitus perustuu raporttiin Hiilamo H., Määttä A., Koskenvuo K., Pyykkönen J., Räsänen T. \& Aaltonen S. (2018). Nuorten osallisuuden edistäminen. Selvitysmiehen raportti. Diak puheenvuoro 11. Diakonia-ammattikorkeakoulu. http://urn.fi/ URN:ISBN:978-952-493-298-1. 
Alatalo, J., Mähönen, E. \& Räisänen, H. (2017). Nuorten ja nuorten aikuisten työelämä ja sen ulkopuolisuus. TEM-analyysejä 76/2017. Helsinki: Työ- ja elinkeinoministeriö.

Anttonen, A. \& Sipilä, J. (2000). Suomalaista sosiaalipolitiikkaa. Tampere: Vastapaino.

Eurofound (2016) Exploring the diversity of NEETs. Luxembourg: Publications Office of the European Union.

Eurofound (2012). NEETs - Young people not in employment, education or training: Characteristics, costs and policy responses in Europe. Luxembourg: Publications Office of the European Union.

EU Commission (2010). Youth on the move. An initiative to unleash the potential of young people to achieve smart, sustainable and inclusive growth in the European Union. Luxembourg: Publications Office of the European Union.

Follesø, R. (2015). Youth at risk or terms at risk? YOUNG: Nordic Journal of Youth Research 23 (3), 240-253.

Furlong, A. (2006). Not a very NEET solution: Representing problematic labour market transitions among early school-leavers. Work, Employment \& Society 20 (3), 553-569.

Halvorsen, B., Hansen, O. J. \& Tägström, J. (2012). Unge på Kanten: Om inkludering av utsatte ungdommer. Copenhagen: Nordic Council of Ministers.

Hiilamo, H. (2010). Pitkäaikaistyöttömän sosiaaliset mahdollisuudet. Teoksessa Hiilamo H. \& Saari J. (toim.) Hyvinvoinnin uusi politiikka - johdatus sosiaalisiin mahdollisuuksiin. Helsinki: Diakoniaammattikorkeakoulu, 265-286.

Hiilamo, H., Määttä, A., Koskenvuo, K., Pyykkönen, J., Räsänen, T. \& Aaltonen, S. (2017a). Nuorten osallisuuden edistäminen. Selvitysmiehen raportti. Diak-puheenvuoroja. http://www. theseus.fi/bitstream/handle/10024/133266/ Puheenvuoro_11_978-952-493-298-1. pdf? sequence $=4$ \&isAllowed $=y$.

Hiilamo, H. T., Komp, K. S., Moisio, P., Sama, T. B., Lauronen, J.-P., Karimo, A. I., Mäntyneva, P., Parpo, A. \& Aaltonen, H. (2017b). Neljä osallistavan sosiaaliturvan mallia. Helsinki: Valtioneuvoston kanslia.
Hyggen, C. (2015). Unge utenfor utdanning og arbeid i Norden. Utfordringer, innsatser og anbefalinger. TemaNord 2015:536.

Hämäläinen, K. \& Hämäläinen, U. (2012). Matkalla maailmalle: nuorten työttömyyden esiintyvyys ja kesto. Työpoliittinen Aikakauskirja 2012 (2), 6-18.

Kraak, A. (2013). State failure in dealing with the NEET problem in South Africa: Which way forward? Research in Post-Compulsory Education 18 (1-2), 77-97.

Käärilä, A. \& Hiilamo, H. (2017). Children in Out-ofhome Care as Young Adults: A Systematic Review of Outcomes in the Nordic Countries. Children and Youth Services Review 79, 107-114.

Larja, A., Törmäkangas, L., Merikukka, M., Ristikari, T., Gissler, M. \& Paananen, R. (2016). NEET-indikaattori kuvaa nuorten syrjäytymistä. Tieto \& Trendit 2016 (2). Helsinki: Tilastokeskus.

Maanselkä, A. (2018). Kannustava perusturva. Helsinki: Kompassi.

Myrskylä, P. (2012). Koulutustaso selittää työurien pituutta. Tieto \& Trendit 2012 (6). Helsinki: Tilastokeskus.

Nilsen, Ø. A. \& Reiso, K. H. (2014). Scarring effects of early-career unemployment. Nordic Economic Policy Review 2014 (1), 13-46.

Ristikari, T., Törmäkangas, L., Lappi, A., Haapakorva, P., Kiilakoski, T., Merikukka, M., Hautakoski, A., Pekkarinen, E. ja Gissler, M. (2016). Suomi nuorten kasvuympäristönä. Helsinki: Nuorisotutkimusseura \& Terveyden ja hyvinvoinnin laitos.

Serracant, P. (2014). A brute indicator for a NEET case: Genesis and evolution of a problematic concept and results from an alternative indicator. Social Indicators Research 117, 401-419.

Schmillen, A. \& Umkehrer, M. (2017). The scars of youth: Effects of early-career unemployment on future employment experiences. International Labour Review 156 (3/4), 465-494.

Yates, S. \& Payne, M. (2006). Not so NEET? A critique of the use of 'NEET' in setting targets for interventions with young people. Journal of Youth Studies 9 (3), 329-344. 